\title{
SIPRI Yearbook 2014
}

SIPRI (Sztokholmski Międzynarodowy Instytut Badań nad Pokojem) systematycznie, od 1966 roku, publikuje rocznik poświęcony takim problemom, jak: światowe wydatki zbrojeniowe, międzynarodowe transfery broni, produkcja zbrojeniowa, siły nuklearne, konflikty zbrojne czy multilateralne operacje pokojowe. Zawarte w nim analizy opierają się na aktualnym (najnowszym) stanie wiedzy m.in. z zakresu kontroli broni, pokoju i bezpieczeństwa międzynarodowego. Ostatnie wydanie (Rocznik, 2014) dotyczy 2013 r. i koncentruje się na trzech wydaje się najważniejszych z punktu widzenia badań nad pokojem kwestiach: bezpieczeństwo i konflikty, wydatki wojskowe i uzbrojenie oraz nieproliferacja, kontrola zbrojeń i rozbrojenie. Niniejsze opracowanie, ze względu na objętość SIPRI Yearbook 2014, zawiera uporządkowane chronologicznie najważniejsze tendencje opublikowane w roczniku.

Wprowadzenie w najnowszym wydaniu zawiera szczegółową analizę narastających i niepokojących, według autorów, tendencji w kontekście trwających konfliktów, dynamiki zbrojeń i bezpieczeństwa międzynarodowego. Podkreślono, że rok 2013 charakteryzował się ciągłymi i nagłymi zmianami, co zwiększa niestabilność obecnego porządku światowego. Owe fluktuacje ładu międzynarodowego zależą głównie od: zdolności państw w dotrzymywaniu przez nie umów międzynarodowych, rozumienia zależności między rozwojem a bezpieczeństwem oraz umiejętnego wykorzystania postępu z obszaru wszystkich dziedzin nauki, który stał się w praktyce niezależnym czynnikiem kształtującym bezpieczeństwo międzynarodowe.

Pozostała część wprowadzenia zawiera omówienie wojny domowej w Syrii i w tej kwestii poruszono szczegółowo trzy elementy: trudności w „mierzeniu” zakresu konfliktu (zbieranie wiarygodnych danych), ograniczanie dostaw broni (rozbieżne stanowiska państw), konsekwencje kontroli zbrojeń w kontekście użycia broni chemicznej. Po pierwsze, dane oparte na przekazach medialnych, w tym na portalach społecznościowych, powodują rozdźwięk w sprawozdaniach, a to przy dezinformacji oraz nieuwierzytelnionych informacjach wymusza na analitykach szczególny rygor metodologiczny. Po drugie, ujawniła się niewielka skuteczność Traktatu o handlu bronią, szczególnie kiedy zróżnicowały się stanowiska w kwestii dostaw broni dla uczestników konfliktu syryjskiego. Po trzecie, wydarzenia w Syrii unaoczniły problem użycia broni chemicznej przez niepaństwowych i państwowych aktorów w spornym regionie.

W głównej części rocznika pierwszy rozdział obejmuje problematykę konfliktów zbrojnych, a dokładniej charakteryzuje opisane wcześniej (we wprowadzeniu) tendencje. Po pierwsze, wzrasta liczba zgonów w wyniku umiędzynarodowionych wewnętrznych konfliktów, szczególnie w rejonie Bliskiego Wschodu. Po drugie, w okresie postzimnowojennym społeczność międzynarodowa była oswajana ze stanowiskiem o słuszności i skuteczności używania siły (interwencji zbrojnych), głównie za sprawą 
Stanów Zjednoczonych. W 2013 r. pojawiły się oznaki zmiany, od kiedy uznano, że przemoc stosowana $\mathrm{w}$ tej formie, jako narzędzie do rozwiązywania konfliktów i terrorystycznych wyzwań, pozostaje ograniczona i coraz bardziej kosztowna w kwestii finansów, ofiar i utraty kapitału politycznego. Po trzecie, sprzeciw parlamentu brytyjskiego wobec użycia siły w Syrii stał się powszechnie postrzegany jako punkt zwrotny w polityce Zachodu, w kierunku ograniczania zaangażowania wojskowego w konfliktach na całym świecie. Po czwarte, mediacje jako jedna z ważnych metod rozwiązywania konfliktów zbrojnych pozostawały w badanym okresie nadal marginalizowane. Po piąte, Organizacja Narodów Zjednoczonych mogłaby podjąć większą odpowiedzialność za zapobieganie konfliktom zbrojnym i za mechanizm ich rozwiązywania. Co więcej, do potwierdzenia tych tez opublikowano szereg zestawień ilościowych (np. schematy zorganizowanej przemocy) oraz The Global Peace Index 2013.

Druga część pierwszego rozdziału obejmuje problematykę operacji pokojowych i zarządzania konfliktem. Zawarty w niej główny trend sprowadza się do dramatycznego ograniczenia personelu rozmieszczonego $\mathrm{w}$ ramach operacji pokojowych, pomimo zaangażowania się Francji w dwie nowe operacje. Poboczne obserwacje to: wzrost międzynarodowego zainteresowania Afryką kosztem Afganistanu; ukierunkowanie interwencji ONZ na zapobieganie ekspansji wszystkich grup zbrojnych oraz na ich „neutralizowanie" i rozbrajanie; ochrona ludności cywilnej, mimo trudności w realizacji, nadal utrzymuje się na wysokiej pozycji na liście priorytetów wielostronnych operacji pokojowych, a nawet można wykazać odnowienie się determinacji w tej kwestii; rozbieżności między Unią Afrykańską, ONZ i afrykańskimi organizacjami regionalnymi poddają w wątpliwość wdrażanie wielopodmiotowych operacji pokojowych, jak Wielowymiarowa Zintegrowana Misja Stabilizacyjna w Mali.

WOLD MILITARY SPENDING, 2013

\begin{tabular}{|l|c|c||}
\hline \multicolumn{1}{|c|}{ Region } & $\begin{array}{c}\text { Spending } \\
\mathbf{( \$ ~ b . )}\end{array}$ & $\begin{array}{c}\text { Cange } \\
\mathbf{\%}\end{array}$ \\
\hline Africa & 44.9 & 8.3 \\
North Africa & 18.7 & 9.6 \\
Sub-Saharan Africa & 26.2 & 7.3 \\
\hline Americas & 736 & -6.8 \\
Central America and the Caribbean & 9.6 & 6.0 \\
North America & 659 & -7.8 \\
South America & 67.4 & 1.6 \\
\hline Asia and Oceania & 407 & 3.6 \\
Central and South Asia & 63.7 & 1.2 \\
East Asia & 282 & 4.7 \\
Oceania & 25.9 & -3.2 \\
South East Asia & 35.9 & 5.0 \\
\hline Europe & 410 & -0.7 \\
Eastern Europe & 98.5 & 5.3 \\
Western and Central & 312 & -2.4 \\
\hline Middle East & 150 & 4.0 \\
\hline World total & $\mathbf{1 7 4 7}$ & $\mathbf{- 1 . 9}$ \\
\hline Spending figures are in current (2013) US\$. All changes are in real terms. \\
\hline
\end{tabular}

Źródlo: (SIPRI Yearbook 2014: 8). 
W drugim rozdziale rocznika SIPRI 2014 zamieszczono analizy z obszaru wydatków wojskowych i uzbrojenia z 2013 roku, w trzech częściach: wydatki na cele militarne i produkcja broni, międzynarodowe przepływy broni, światowy potencjał nuklearny. Opublikowane liczne zestawienia ilościowe unaoczniły poniższe tendencje (1-2 z części pierwszej, 3-8 z części drugiej, 9-10 z części trzeciej). Po pierwsze, cywilizacja zachodnia (Europa, Ameryka Północna, Oceania) ogranicza wydatki na zbrojenia (o 13,5 procent), z powodu stagnacji gospodarczej i chęci minimalizowania deficytu budżetowego, w przeciwieństwie do reszty świata, gdzie dochodzi do ograniczonego wyścigu zbrojeń ze względu na połączenie wzrostu gospodarczego, obaw związanych z bezpieczeństwem, ambicji geopolitycznych i często wewnętrznych czynników politycznych.

Po drugie, wzrasta znaczenie (udział w rynku) przedsiębiorstw ze „,wschodzących” regionów (dyfuzja przemysłu zbrojeniowego), choć nadal dominują w TOP 100 tradycyjni (zachodni) producenci uzbrojenia. Po trzecie, wielkość międzynarodowych transferów broni wzrosła o 14 procent w latach 2009-2013 w stosunku do okresu 2004-2008. Po czwarte, zmniejszenie się zamówień wewnętrznych skutkowało dodatkową presją w krajach produkujących broń, aby znacząco zwiększyć udział eksportu w ich całkowitej sprzedaży poprzez poszukiwanie nowych rynków eksportowych (rządowe wsparcie sprzedaży, promocje itp.). Po piąte, inną konsekwencją ograniczonych budżetów wojskowych był znaczący spadek międzynarodowych przepływów broni do państw europejskich, mimo wzrostu w Azji i Afryce. Po szóste, zwiększa się w uzbrojeniu udział pocisków kierowanych dalekiego zasięgu, co zakłóca regionalną równowagę konwencjonalnych i nuklearnych sił zbrojnych oraz zwiększa prawdopodobieństwo wojny. Po siódme, główne państwa (dostawcy) regularnie wykazują gotowość do eksportu pocisków kierowanych, nawet do obszarów o wysokim poziomie napięć i państw posiadających broń nuklearną, pomimo przyjętych kontroli (ograniczeń) w rozprzestrzenianiu tego rodzaju broni. Po ósme, oficjalne raporty na temat transferu broni, istotne dla oceny aktywności państwa w zakresie zbrojeń, rozczarowują w kontekście ich przejrzystości, szczególnie ten problem dotyczy dostawców z ChRL, Izraela i Rosji. Po dziewiąte, łączna liczba głowic jądrowych na świecie spada,

NUCLEAR FORCES OF THE 5 LEGALLY RECOGNIZED NUCLEAR WEAPON STATES, $1970-2014$

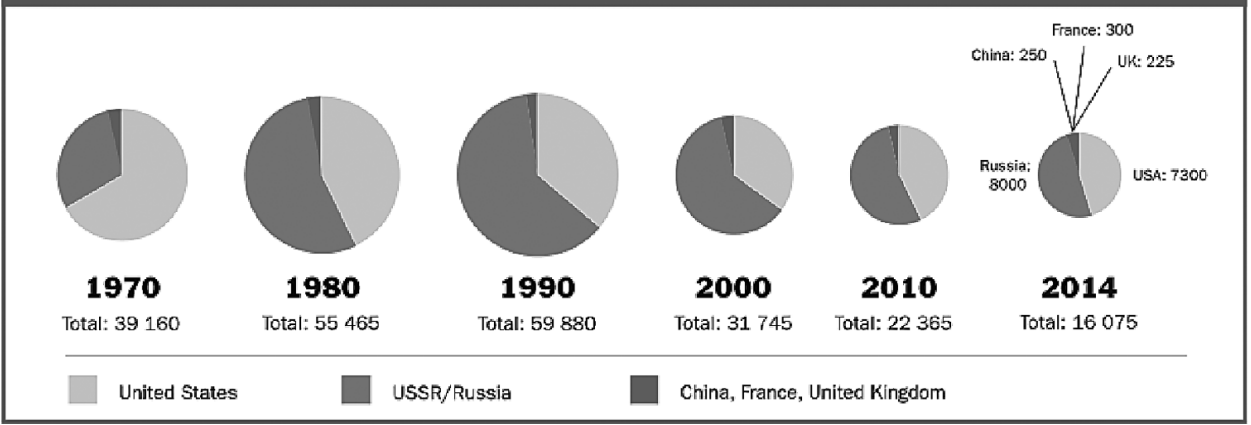

Źródło: (SIPRI Yearbook 2014: 12). 
głównie ze względu na redukcje traktatowe USA i Rosji, choć nadal te dwa państwa posiadają 90\% światowych zapasów broni. Po dziesiąte, istnieje deficyt wiarygodnych informacji na temat stanu arsenałów i możliwości nuklearnych państw uzbrojonych w głowice jądrowe.

W trzecim i ostatnim rozdziale (nieproliferacja, kontrola zbrojeń i rozbrojenie) analizę tej problematyki podzielono na cztery główne wątki: kontrola zbrojeń nuklearnych i nieproliferacja, redukcja zagrożeń w kontekście materiałów chemicznych i biologicznych, kontrola broni konwencjonalnej i budowa militarnego zaufania oraz kontrola przepływu uzbrojenia. W pierwszym, główne spostrzeżenie sprowadza się do obaw o proliferację broni jądrowej za sprawą irańskiego i północnokoreańskiego programu jądrowego. Co więcej, podtrzymuje się stanowisko o pacie w rozbieżnościach interpretacyjnych poszczególnych państw w kwestii prawa do energii nuklearnej w ramach Ukladu o nierozprzestrzenianiu broni jadrowej, co urealnia militarne ataki prewencyjne opóźniające wdrażane programy nuklearne. W konsekwencji w $2013 \mathrm{r}$. rosła międzynarodowa frustracja z powodu braku postępów w procesie wielostronnego rozbrojenia nuklearnego. W drugim wątku (redukcja zagrożeń w kontekście materiałów chemicznych i biologicznych), Autorzy rocznika podkreślali wysiłki międzynarodowe w opracowaniu strategii zapobiegania i naprawiania skutków niewłaściwego wykorzystania toksycznych substancji chemicznych i materiałów biologicznych. Ponadto za najważniejsze wydarzenie z zakresu omawianej problematyki uznali rozpoczęcie procesu likwidacji arsenału broni chemicznej i biologicznej w Syrii, a dokładniej gotowość i wysiłki na rzecz zapewnienia, że nauka i technologia nie są i nie będą nadużywane w działaniach wojennych. Trzeci wątek (kontrola broni konwencjonalnej i budowa militarnego zaufania) ujawnia coraz bardziej niebezpieczną tendencję nienadążania przez prawodawców za dynamicznymi zmianami otoczenia, w którym funkcjonujemy. Nastała pilna konieczność uregulowania i powstrzymania w części określonych zachowań podmiotów niepaństwowych, szczególnie w dobie nowych technologii umożliwiających nietradycyjną działalność. Poprzez postęp techniczny i technologiczny wyłonił się nierozstrzygnięty problem granicy między humanitarnym a niehumanitarnym rodzajem broni (np. stosowanie improwizowanego ładunku wybuchowego). W czwartym wątku w syntetyczny sposób opisano postęp jaki dokonał się w globalnych wysiłkach na rzecz wzmocnienia kontroli nad handlem bronią konwencjonalną (Traktat o handlu bronia). Nie był to przełom z 2013 roku, ale efekt systematycznego (w ostatnich latach) zbliżania się państw do traktatowego konsensusu. Dodatkowo przedstawiono próby ograniczenia handlu bronią poprzez wielostronne embarga na dostawy broni, choć te inicjatywy wywołały mieszane skutki. Na końcu rocznika SIPRI dołączono aneksy (syntetyczne i chronologiczne).

\section{Bibliografia}

SIPRI Yearbook 2014. Armaments, Disarmament and International Security (2014), Stockholm International Peace Research Institute, Stockholm. 


\title{
STRESZCZENIE
}

Ostatnie wydanie SIPRI Yearbook 2014 dotyczy 2013 r. i koncentruje się na trzech wydaje się najważniejszych z punktu widzenia badań nad pokojem kwestiach: bezpieczeństwo i konflikty, wydatki wojskowe i uzbrojenie oraz nieproliferacja, kontrola zbrojeń i rozbrojenie. Niniejsze opracowanie zawiera uporządkowane chronologicznie najważniejsze tendencje opublikowane w roczniku.

\section{SIPRI YEARBOOK 2014}

\begin{abstract}
The latest SIPRI Yearbook 2014 focuses on three most important questions crucial for peace research: (1) security and conflicts; (2) military spending and armaments; (3) non-proliferation, arms control and disarmament. The material contains chronologically ordered tendencies published in the Yearbook.
\end{abstract}


